\title{
Philippe Berthier, Pierre Herbart. Morale et style de la désinvolture
}

\section{Emanuele Kanceff}

\section{(2) OpenEdition}

1 Journals

\section{Edizione digitale}

URL: https://journals.openedition.org/studifrancesi/41172

DOI: 10.4000/studifrancesi.41172

ISSN: 2421-5856

\section{Editore}

Rosenberg \& Sellier

\section{Edizione cartacea}

Data di pubblicazione: 1 juillet 2004

Paginazione: 220

ISSN: 0039-2944

\section{Notizia bibliografica digitale}

Emanuele Kanceff, «Philippe Berthier, Pierre Herbart. Morale et style de la désinvolture», Studi Francesi

[Online], 142 (XLVIII | I) | 2004, online dal 30 novembre 2015, consultato il 09 septembre 2021. URL: http://journals.openedition.org/studifrancesi/41172; DOI: https://doi.org/10.4000/studifrancesi. 41172

Questo documento è stato generato automaticamente il 9 septembre 2021.

\section{(c) (1)}

Studi Francesi è distribuita con Licenza Creative Commons Attribuzione - Non commerciale - Non opere derivate 4.0 Internazionale. 


\title{
Philippe Berthier, Pierre Herbart. Morale et style de la désinvolture
}

\author{
Emanuele Kanceff
}

\section{NOTIZIA}

PHILIPPE BERTHIER, Pierre Herbart. Morale et style de la désinvolture, Tupin-et-Semons, Centre d'Études Gidiennes, 1998, pp. 140.

1 Con questo libro di Philippe Berthier assistiamo ad un fenomeno raro, che ha del miracoloso: la trasformazione di un libro di cultura in romanzo, o di un racconto preso dal vivo in uno studio scientifico.

2 Perché, con il suo stile leggero, con la sua verve e il suo linguaggio di favola, Berthier ci racconta, con tutte le necessarie pezze d'appoggio, la reale avventura umana, di colui che fu uno degli intimi di André Gide, marito della figlia della «Petite dame», prosatore e poeta, giornalista, ma anche organizzatore del viaggio in URSS di Gide, suo compagno di viaggi e di lavoro, autore di un libro non dimenticato su di lui, À la recherche d'André Gide (Gallimard, 1952). 